\title{
Enforcing Democracy at the Regional Level: Paraguay's Suspension before the Mercosur Court
}

\author{
Geraldo Vidigal $^{*}$
}

\section{Keywords}

International trade, regional trading agreements, Mercosur, democracy enforcement

Inaugurated in 1991 as a regional trade agreement between Argentina, Brazil, Paraguay and Uruguay (M4), the Common Market of the South (Mercosur) followed an increasingly familiar pattern, serving as an institutional framework for harmonisation of wider economic and social policies between its members. In 1998, following allegations of an attempted coup in Paraguay, the M4, Chile and Bolivia agreed on a Protocol on Democratic Commitment in Mercosur (Ushuaia Protocol), ${ }^{1}$ whose Article 5 empowers parties to regional agreements, acting by consensus, to respond to a 'breakdown of democracy' in one of them by suspending the latter's rights under the relevant agreements.

On 29 June 2012, following a hasty deposition of Paraguay's President by the country's Congress, the presidents of Argentina, Brazil and Uruguay (M3) decided to suspend Paraguay's rights to participate in Mercosur decision-making. Paraguay responded by initiating a dispute before Mercosur's Permanent Review Court (Mercosur Court), invoking the emergency procedure provided for in Article 24 of the 2002 Olivos Protocol for the Solution of Controversies in the Mercosur (Olivos Protocol). ${ }^{2}$ Paraguay claimed that its suspension was null and void and, more importantly, that one of its consequences-the accession of Venezuela to Mercosur-should be reversed as a result. In less than two weeks,

PhD candidate, Sidney Sussex College, University of Cambridge; European Marie Curie Fellow, DISSETTLE Program, Bocconi University in Milan. The author would like to thank Daniel Arbix for the careful revision and comments.

1 Ushuaia Protocol on Democratic Commitment in the Mercosur, the Republic of Bolivia and the Republic of Chile, 24 July 1998, 2177 UNTS 375.

2 Olivos Protocol for the Solution of Controversies in the Mercosur, 18 February 2002, 2251 UNTS 244.

Copyright $\odot$ the Author(s).

This work is licensed under a Creative Commons Attribution-NonCommercial-NoDerivs 3.0 License. 
the Court issued an award $(\text { Award } 1 / 2012)^{3}$ which, despite not having examined the merits of the case, clarified some relevant institutional matters in Mercosur law. If Paraguay takes the case forward, the Court may be required to determine the extent of its powers of judicial review over political decisions of members.

\section{Background}

On 21 and 22 June 2012, President Fernando Lugo of Paraguay was impeached by the Paraguayan Congress. On 21 June, the Chamber of Deputies formulated and approved, by 76 votes to 1 , an accusation against the President for 'bad performance of his functions' (a reason for impeachment under Article 225 of the Paraguayan Constitution). ${ }^{4}$ The next day the Senate took up the case. Lugo and his lawyers had less than 24 hours to examine the indictment and prepare the defence. A trial was conducted by the Senate and, within five hours, Lugo's impeachment was approved by 39 votes to 1 . The Vice-President, Federico Franco, took office immediately.

On 24 June, the M3, plus the five Mercosur associate states (Bolivia, Chile, Colombia, Ecuador and Peru) and Venezuela (then in accession process), condemned the 'breakdown of democracy' in Paraguay. In a Mercosur summit held on 28 and 29 June (Mendoza summit), the M3 presidents invoked the Ushuaia Protocol and suspended Paraguay from its participation in Mercosur decisionmaking (Mendoza decision). ${ }^{5}$ The Mendoza decision specifically suspended in relation to Paraguay the provision, in Article 40(ii) of the Protocol on the Institutional Structure of the Mercosur (Institutional Protocol), ${ }^{6}$ that all members must incorporate a Mercosur norm into their domestic legal order before it enters into force. As a consequence, pursuant to Article 40(iii) of the same protocol, Mercosur norms would enter into force 30 days after their incorporation in the domestic legal orders of the M3. ${ }^{7}$

3 Laudo No 01/2012 (Award 1/2012), Tribunal Permanente de Revisión del Mercosur, 21 July 2012, <http://www.mercosur.int> [accessed 1 March 2013].

4 Constitución Política de la República de Paraguay, 20 June 1992, http://www.senado.gov.py/leyes [accessed 1 March 2013].

5 Decisión sobre la Suspensión del Paraguay en el Mercosur en Aplicación del Protocolo de Ushuaia sobre Compromiso Democrático, MERCOSUR/CMC/DEC. No 28/12, 29 June 2012 (Mendoza decision).

6 Additional Protocol to the Asunción Treaty on the Institutional Structure of Mercosur (Ouro Preto Protocol), 17 December 1994, 2145 UNTS 300. To facilitate the reading for non-specialists, the terminology used in this article will at times be at variance with the Mercosur tradition of referring to the various instruments by the name of the city where they were signed.

7 Mendoza decision, Art 2. 
Venezuela's accession, decided by unanimity by the M4 in 2006, had been approved domestically by the M3 but not by Paraguay. Following the Mendoza decision, the M3 presidents issued a declaration acknowledging the accession of Venezuela to Mercosur and calling a Mercosur meeting for the formal accession to take place (Mendoza declaration). ${ }^{8}$ In response, on 9 July 2012 Paraguay filed a claim with the Mercosur Court against the M3, challenging the validity of the Mendoza decision and of the Mendoza declaration.

\section{Decision of the Court}

Three questions were posed before the Mercosur Court: (i) whether the Court had jurisdiction to examine Paraguay's challenge of the Mendoza decision and Mendoza declaration; (ii) whether the emergency procedure could be invoked by Paraguay in the circumstances; and (iii) whether the Mendoza decision and Mendoza declaration were valid.

\subsection{Jurisdiction of the Court}

The defendants argued that the dispute was not a commercial but a political one, as the Mendoza decision concerned the issue of democracy. Decisions under the Ushuaia Protocol, they claimed, were not decisions of Mercosur organs and fell outside the jurisdiction ratione materiae of the Mercosur dispute settlement system. Members had 'exclusive authority' to interpret the meaning of 'breakdown of democracy', and a court of law had no 'aptitude' to second-guess decisions of the members on political issues. ${ }^{9}$

The Court dismissed these arguments. It noted that pursuant to Article 1.1 of the Olivos Protocol, Mercosur dispute settlement concerns disputes 'regarding the interpretation, application or breach of' the Mercosur Constitutive Treaty (Constitutive Treaty), ${ }^{10}$ its side agreements and protocols thereto, as well as decisions, resolutions and directives issued by Mercosur organs. ${ }^{11}$ Nowhere in the Olivos Protocol is the jurisdiction of the Court restricted to trade matters.

8 Declaración sobre la Incorporación de la República Bolivariana de Venezuela al Mercosur, 29 June 2012, Art 1-2.

9 Award 1/2012, para 27.

${ }^{10}$ Treaty Establishing a Common Market (Asunción Treaty) between the Argentine Republic, the Federative Republic of Brazil, the Republic of Paraguay and the Eastern Republic of Uruguay, 26 March 1991, 2140 UNTS 257.

${ }^{11}$ Award 1/2012, paras 34-5. 
Furthermore, the preamble as well as the provisions of the Ushuaia Protocol make explicit reference to this protocol's integration within the Mercosur legal system. The Court stated that the rules of the Ushuaia Protocol are a matter for Mercosur dispute settlement, 'to the extent that they affect or may affect the rights and obligations of members.'

\subsection{Use of the emergency procedure}

The emergency procedure under which Paraguay filed its claim was based on Article 24 of the Olivos Protocol. Ordinarily, Mercosur dispute settlement procedure is initiated by recourse to ad hoc arbitral tribunals, against whose awards members may then appeal to the Mercosur Court. Article 24, however, merely empowers the Common Market Council (Mercosur's highest decision-making body) to create special procedures. The only procedure created by the Council, through Decision $23 / 04{ }^{13}$ concerns disputes relating to perishable or seasonal goods-allowing for these disputes direct recourse to the Mercosur Court. The only other possibility for the Mercosur Court to hear a dispute directly is, pursuant to Article 23 of the Olivos Protocol, by agreement of the parties to the dispute. The defendants explicitly rejected direct recourse to the Court. Arguing that its suspension from political bodies prevented it from having recourse to the ordinary procedure, Paraguay nonetheless filed its claim directly with the Mercosur Court, requesting use by analogy of the emergency procedure.

The Court rejected the analogy. It felt unable to 'substitute its will for that of the members manifested in the requirements provided for in Decision 23/04, which limit the jurisdiction of the Mercosur Court in relation to the special emergency procedure. ${ }^{14}$ Furthermore, the Court noted that Paraguay had not formally requested direct negotiations prior to initiating the dispute-a requirement under Article 4 of the Olivos Protocol. While acknowledging that the resulting delay could be prejudicial to Paraguay's interests and even to 'the legal-institutional stability in the region', the Court found that it could not place itself above the text of the Olivos Protocol. ${ }^{15}$

\footnotetext{
${ }^{12}$ Ibid, para 40.

${ }^{13}$ Procedimiento para atender los casos excepcionales de urgencia, a que hace referencia el artículo 24 del Protocolo de Olivos para la Solución de Controversias en Mercosur, MERCOSUR/CMC/DEC. No 23/04, 7 July 2004.

${ }^{14}$ Award 1/2012, para 52.

${ }^{15}$ Ibid, paras 58-9.
} 
Against this, a minority opinion argued for a teleological interpretation of Mercosur law. The minority agreed that Paraguay could not have had recourse to the emergency procedure by analogy. ${ }^{16}$ However, it reasoned that the purpose of Mercosur dispute settlement is to solve disputes between members arising out of Mercosur law, observing that the Olivos Protocol provides for the possibility of exceptional and urgent measures in case of irreparable damage. The minority concluded that direct recourse to the Court should be permitted when other procedures are not available to a member because it has been excluded from Mercosur organs. ${ }^{17}$

\subsection{Merits of the dispute and future of the claim}

Having found that the procedure chosen by Paraguay was not adequate for the dispute, the Mercosur Court concluded that it had no jurisdiction to examine the merits of the case. The Court nonetheless considered some substantive aspects of the dispute. First, it understood that Paraguay's suspension from decision-making did not affect its right to have recourse to Mercosur dispute settlement, and recognised the Minister of Foreign Affairs appointed by Paraguay's new President as that member's rightful representative. ${ }^{18}$ Second, the Court explicitly left open the possibility of recourse by members to other means within Mercosur law to resolve the dispute. ${ }^{19}$ These findings, together with the Court's determination that it has jurisdiction ratione materiae, provided Paraguay with assurances that it may proceed with its case.

The subsequent presentation by Paraguay of formal protests to the M3 may indicate a willingness to push the case forward. ${ }^{20}$ However, these protests fail to comply with the requirements the Mercosur Court held indispensable for a communication leading to the establishment of a Mercosur dispute. ${ }^{21}$ In particular, Paraguay's protest does not include a proposed date and place for direct negotiations with its addressees.

Another possibility could be for Paraguay to shift fora and file a claim before the International Court of Justice (ICJ). One problem with this option would be to

\footnotetext{
${ }_{16}$ Minority opinions in Mercosur law are anonymous.

${ }^{17}$ Ibid, paras 61-5.

${ }^{18}$ Ibid, paras 6 and 28.

${ }^{19}$ Ibid, para 4.

${ }^{20}$ Ministry of Foreign Affairs, 'Presentación de protesta dirigida a los Gobiernos de Argentina, Brasil y Uruguay', <http://www.mre.gov.py/v1/Noticias/175-presentacin-de-protesta-dirigidaa-los-gobiernos-de-argentina-brasil-y-uruguay.aspx> [accessed 1 March 2013].

${ }^{21}$ Award 1/2012, para 60 n 6.
} 
find grounds for jurisdiction. Brazil and Uruguay, as well as Paraguay, are parties to the Pact of Bogotá, ${ }^{22}$ which provides for compulsory jurisdiction under Article 36(2) of the Statute of the ICJ between its signatories. ${ }^{23}$ Argentina and Venezuela, however, signed but never ratified the Pact. Even though Paraguay could enter claims against Brazil and Uruguay only, it is unlikely that the ICJ will agree to adjudicate on the matter. In order to do so, the ICJ would be required to rule on the lawfulness of Argentina's conduct, as well as on the rights of Venezuela under Mercosur law. The ICJ has often refused to adjudicate when it found that a non-party's legal interests 'would form the very subject-matter of the decision. ${ }^{24}$ Unless some other grounds for jurisdiction can be found, then, Mercosur dispute settlement appears to be the sole means available for Paraguay to have its claim heard.

\section{The legality of the suspension}

This section considers the merits of Paraguay's allegations. Paraguay alleged, first, that the M3 presidents were not competent to make a decision having effect upon Mercosur law. It also argued that, under the Ushuaia Protocol, any such decision should have been preceded by consultations. Finally, Paraguay claimed that Article 20 of the Constitutive Treaty specifically provides that approval of requests for accession requires unanimity among existing members.

\subsection{The competence of the M3 presidents}

Paraguay challenged the competence of the M3 presidents to issue the Mendoza decision, arguing that joint presidential decisions are not sources of Mercosur law. A list of sources is provided for in Article 41 of Mercosur's Institutional Protocol. These include: (i) the Constitutive Treaty, its protocols and additional or complementary instruments; (ii) agreements entered into within the framework of the Constitutive Treaty and its protocols; and (iii) decisions of the Common

\footnotetext{
${ }^{22}$ American Treaty on Pacific Settlement (Pact of Bogotá), 30 April 1948, 30 UNTS 55. Paraguay and Uruguay have also independently accepted the Court's compulsory jurisdiction under Article 36(2), vis-à-vis other states also accepting this compulsory jurisdiction.

${ }^{23}$ Statute of the International Court of Justice, 26 June 1945, 33 UNTS 993, Art 36(2).

${ }^{24}$ There is nonetheless margin for debate, especially if the claim is framed in terms of responsibility instead of legality. Contrast Certain Phosphate Lands in Nauru (Nauru v Australia), ICJ Reports 1992 p 243, 259-261, with Application of the Interim Accord of 13 September 1995 (The Former Yugoslav Republic of Macedonia v Greece), Judgment of 5 December 2011, para 43.
} 
Market Council, resolutions of the Common Market Group and directives of the Mercosur Trade Commission. Paraguay's argument appears to be that only organs mentioned in item (iii) may make binding decisions under Mercosur law. ${ }^{25}$ This, however, overlooks the possibility of decisions being lawfully made under the treaties, protocols and agreements referred to in items (i) and (ii). The Mercosur Court determined in Award 1/2012 that the Ushuaia Protocol is part of Mercosur law for the purposes of its jurisdiction. It would seem contradictory for the Court to later determine that an express provision in the same protocol cannot serve as a valid basis for a decision under Mercosur law. Article 5 of the Ushuaia Protocol explicitly authorises 'the other States parties to this Protocol' to consider which measures to take in case of a breakdown of democracy in one of the members. Article 6 specifies that the state targeted by the measures 'shall be notified of them but shall not participate in the process of their adoption.' 6

Even if this were not specifically provided for, it would be difficult to argue that a unanimous decision by all members except for an alleged violator does not produce any effects. Under general international law, a violation of a multilateral treaty may lead to the effective expulsion of a party from the treaty, or to suspension of its rights under it. Article 60(2)(a) of the Vienna Convention on the Law of Treaties $(V C L T),{ }^{27}$ ratified by all M4, provides that a 'material breach' of a multilateral treaty allows 'the other parties by unanimous agreement to suspend the operation of the treaty in whole or in part or to terminate it', either entirely or between themselves and the violator only.

A material breach is defined as a 'violation of a provision essential to the accomplishment of the object and purpose of the treaty. ${ }^{28}$ Although originally a trade bloc, Mercosur has developed over two decades into a multi-dimensional integration process, involving coordination of economic and social policies between its members, as well as political commitments. If the maintenance of democracy is in fact an 'indispensable condition for development of the process of integration', as Article 1 of the Ushuaia Protocol puts it, a breakdown of democracy constitutes a material breach, allowing the other members to suspend, and even terminate, the Mercosur treaties with regard to the violator.

As lex specialis, the Ushuaia Protocol in fact limits the rights of other members to react to a breakdown of democracy in one of them. The measures which Article 5 warrants range from 'suspension of the right to participate in various

\footnotetext{
${ }^{25}$ Award 1/2012, para 12.

${ }^{26}$ Ushuaia Protocol, Art 6.

${ }^{27}$ Vienna Convention on the Law of Treaties, 23 May 1969, 115 UNTS 331.

${ }^{28}$ Ibid, Art 60(3)(b).
} 
bodies of the respective integration processes' to 'suspension of the rights and obligations resulting from those processes'. Other members may not, it would seem, terminate the relevant treaties, or expel the violator, as would be permitted under the VCLT. Additionally, Article 7 provides that the suspension must end as soon as democracy is re-established.

\subsection{Was the Mendoza decision illegal? Formal and substantive aspects}

The other arguments raised by Paraguay concern the form and substance of the Mendoza decision. First, Paraguay claims that the Ushuaia Protocol conditions the taking of Article 5 measures upon prior consultations with the alleged violator. Second, it argues that the Mendoza decision could not have overridden Article 20 of the Constitutive Treaty, which specifically provides that approval of requests for accession 'shall be the subject of unanimous decision by the members'.

The success of both arguments, of course, rests on the premise that the Mendoza decision is subject to review by Mercosur courts. Judicial review of decisions of 'political' organs has sometimes been contentious, in particular for the ICJ in relation to the UN Security Council. ${ }^{29}$ However, the Mercosur Court determined without hesitation that there is a 'right to have recourse to the system' held by any member that considers that its rights under Mercosur law have been violated, adding that its jurisdiction 'encompasses the norms of the Ushuaia Protocol insofar as these norms affect or may affect rights and obligations of any members. ${ }^{30}$ Even if the M3 presidents do not formally constitute a Mercosur organ, then, it seems that the Mercosur Court is willing to review, in light of Mercosur law, both the legality of their decisions and the extent of the effects they may lawfully produce upon Mercosur treaty rights.

\subsection{The duty to consult and the formal legality of the measure}

Paraguay's argument regarding the formal illegality of the Mendoza decision is based on Article 4 of the Ushuaia Protocol, which provides that, in the event of a breakdown of democracy in a party, other parties 'shall promote

\footnotetext{
${ }^{29}$ Aerial Incident at Lockerbie (Libyan Arab Jamahiriya v United States of America), ICJ Reports $1998 \mathrm{p}$ $115,129-34$

${ }^{30}$ Award 1/2012, para 40.
} 
the relevant consultations among themselves and with the State concerned'. Article 5 conditions the taking of further measures to such consultations being unsuccessful. Paraguay argued that pertinent consultations never took place, while the defendants rebutted that (i) no formal requirements attach to the duty to consult, as it is political in character; and (ii) they did in fact consult with 'various Paraguayan political actors' before making the decision. ${ }^{31}$

Having affirmed, in Award 1/2012, broad powers of judicial review in Mercosur, the Mercosur Court is unlikely to accept the argument that the 'political' character of consultations shields them from judicial oversight. More weight may be given to the argument that no particular forms or time frames attach to consultations under the Ushuaia Protocol. Article 4 of the Ushuaia Protocol provides that consultations must be 'relevant'-they must specifically refer to the obligations under the protocol-and must include 'the State concerned'. Arguably, both requirements were met by the presence in Paraguay, on the critical days of the impeachment, of a delegation of representatives of the Union of South American Nations (UNASUR), including all three M3 Ministers of Foreign Affairs. This delegation held meetings with then President Lugo and senators, as well as with members of the Paraguayan military. If the new executive is not recognised by the other members, it would seem that the legislature and the military constitute rightful representatives of the Paraguayan state, and-especially when their position is of support for the new executive-may be consulted with in order to assess the existence of a breakdown of democracy.

Additionally, the Mendoza decision was made in a scenario in which all three branches of government in Paraguay supported the impeachment. The decision was issued four days after Paraguay's Supreme Court dismissed the appeal lodged by (former) President Lugo against his impeachment. The main grounds for the Supreme Court's decision were: (i) that the Senate was exercising a 'political judgement' and was acting within its constitutional competences; (ii) that, since the procedure that was 'not technically speaking jurisdictional', judicial guarantees apply 'not in an absolute but in a relative manner'; and, strikingly, (iii) that, since the procedure to which it applied was over, 'the challenged resolution lost its legal utility, to which attaches the dismissal in limine litis of the claim.' ${ }^{32}$ Lugo's successor formed his government on the same day, and the President of

\footnotetext{
${ }^{31}$ Ibid, paras 22-3.

${ }^{32}$ Corte Suprema de Justicia del Paraguay, Acción de Inconstitucionalidad No 874, 25 June 2012. The Supreme Court reaffirmed its position on 20 September 2012 (Acción de Inconstitucionalidad No 960).
} 
Congress declared the change of government 'irreversible'. No further remedies existed within the Paraguayan legal system capable of reversing Lugo's ousting.

The ICJ has consistently held that treaty clauses requiring previous negotiations do not pose an obstacle to international action if negotiations 'have failed or become futile or deadlocked. ${ }^{33}$ This jurisprudence refers to negotiations that must precede the filing of a claim with the ICJ, but the principle that an obligation to negotiate rests on the premise that a negotiated solution is feasible applies to political fora as well. ${ }^{34}$ If Lugo's removal from office effectively constituted a breakdown of democracy, this series of events would seem to prevent any consultations from being successful, thus permitting the taking of Article 5 measures by other members.

\subsection{Constitutional limitations on the reach of collective decisions}

Even if the Mendoza decision were formally valid, Paraguay argued, it could not have suspended the requirement of unanimity for the acceptance of new members into Mercosur. Article 20 of the Constitutive Treaty specifically provides that approval of requests for accession 'shall require unanimous decision' of Mercosur members. The respondents rebutted this by distinguishing between the decision to accept the accession of a new member and the conditions for this decision to enter into force. Article 20, they argued, applies only to the former; Venezuela's Accession Protocol, ${ }^{35}$ approved unanimously in 2006, would enter into force 30 days 'after the date of deposit of the last instrument of ratification by the non-suspended parties. ${ }^{36}$

This argument by the respondents appears weak. Article 12 of Venezuela's Accession Protocol in fact provides that the protocol should enter into force on the $30^{\text {th }}$ day 'from the date of deposit of the fifth instrument of ratification'. This may be interpreted as poor drafting, but seems to confirm the general principle that decisions in Mercosur, especially decisions as relevant as the incorporation of a new member, should be unanimous. As the Mercosur Court explained in

\footnotetext{
${ }^{33}$ Case concerning Application of the International Convention on the Elimination of all Forms of Racial Discrimination (Georgia v Russian Federation), Judgment of 1 April 2011, paras 156-61.

${ }^{34}$ It is beyond the scope of this article to discuss the distinction between obligations of 'negotiation' and 'consultation'. Arguably, the latter are less stringent than the former.

${ }^{35}$ Protocolo de Adhesión de la Republica Bolivariana de Venezuela al Mercosur, 4 July 2006, $<$ http://www.mercosur.int $>$ [accessed 1 March 2013].

${ }^{36}$ Award 1/2012, para 26.
} 
Award 1/2012, the Mercosur legal framework 'does not create a supranational legal order capable of substituting the sovereign will of its component states. ${ }^{37}$ In this regard, it would be difficult to argue that a decision may affect Paraguay without its full consent. Despite corresponding to the text of the Constitutive Treaty, the distinction made by the M3 between the quora for approval and for ratification seems artificial. It is also contradicted by the signature, on 7 December 2012, of Bolivia's Accession Protocol by the M3, Venezuela and Bolivia, ${ }^{38}$ with Article 13 providing that 'other signatories to the Constitutive Treaty' may later adhere to the protocol.

There are, however, two sides to the Court's dictum. The will of members 'manifests itself ... in the international treaties to which they subscribe and in the decisions subsequently adopted. ${ }^{39}$ Paraguay gave its sovereign consent to the Ushuaia Protocol as much as to the Constitutive Treaty. The former is lex posterior, and arguably also lex specialis. A breakdown of democracy allows other parties to respond by suspending a variety of rights, including 'the rights and obligations deriving from' the various integration processes existing among the parties to the Ushuaia Protocol. More generally, if Mercosur can be considered to have evolved from a one-dimensional trade bloc into a comprehensive integration process, having as one of its pillars the democratic stability of its members, it seems logical to allow the suspension of a member following a breakdown of democracy to have broad effects.

\section{Conclusion: Should Mercosur courts review the substance of the Mendoza decision?}

On the merits, if Paraguay pushes its case forward, Mercosur courts seem to have two options: they may either fully accept the validity of the Mendoza decision or consider that, although generally valid, the decision may not override the unanimity requirement in Article 20 of the Constitutional Treaty. In the latter case, the Mendoza declaration would be without legal effects and Paraguay's consent would be required for Venezuela to accede to Mercosur. Such a decision would also render Bolivia's Accession Protocol, signed on 7 December 2012 under protests by Paraguay, devoid of legal effects pending Paraguay's acceptance.

\footnotetext{
${ }^{37}$ Ibid, para 42.

${ }^{38}$ Protocol de Adhesión del Estado Plurinacional de Bolivia al Mercosur, 7 December 2012, <http://www.mercosur.int> [accessed 1 March 2013].

${ }^{39}$ Award 1/2012, para 42.
} 
It does seem in accordance with the spirit of Mercosur law to prevent some members from introducing new elements into the bloc taking advantage of a momentary suspension of one of them. In case of a more durable breakdown of the democratic process, however, should Article 20 bar all further expansion of Mercosur? In this situation, the sole possibility left for members to go forward with the integration process of Latin America (an explicit objective of the Constitutive Treaty) would be to acknowledge the failure of Mercosur sanctions and to use their residual right under general international law to expel the non-democratic member. ${ }^{40}$ This would run contrary to the contemporary belief that engaging with violators, especially in the case of human rights norms, is more effective than excluding them from the relevant legal framework. ${ }^{41}$ The Court would nonetheless be protecting the principle of unanimity in Mercosur, in line with the bloc's non-supranational character.

Much seems to turn on whether one considers that the events in Paraguay constituted a 'constitutional coup' or whether they were a lawful-if not particularly orderly-application of Paraguay's Constitution. Paraguay's post-ousting government was composed as provided for in the Constitution, and appears willing to hold elections in 2013 as scheduled, triggering a relatively quick readmission to full participation in the trade bloc. On the other hand, Article 17 of the Paraguayan Constitution provides for a series of 'procedural rights' applicable to any 'procedure ... from which a penalty or sanction may derive', some of which were admittedly not respected due to the 'political' character of Lugo's trial. ${ }^{42}$ But may Mercosur courts look beyond the formal validity of the Mendoza decision, determining whether the terms of the suspension were proportional to the gravity of the breakdown of democracy? Undertaking such a review would not only demand a complex examination of the impeachment under Paraguayan law and human rights standards (international or Mercosur-specific); it would also require an important change in mindset from a Court which just rejected a request for teleological interpretation, emphasising the absence of supranationality in Mercosur law.

A less daring option would be for Mercosur courts to affirm a wide margin of appreciation for members on political issues, while safeguarding the courts' ultimate ability to override clearly disproportional uses of Ushuaia Protocol

\footnotetext{
${ }^{40}$ B Simma \& D Pulkowski, 'Of Planets and the Universe: Self-contained Regimes in International Law' (2006) 17 EJIL 483, 492-3.

${ }^{41}$ B Simmons, Mobilizing for Human Rights: International Law in Domestic Politics (2009).

${ }^{42}$ Corte Suprema de Justicia del Paraguay, Acción de Inconstitucionalidad No 874, 25 June 2012, para 3.
} 
sanctions. Save for cases of obvious abuse, it is difficult to fashion clear legal standards on what constitutes a breakdown of democracy: the decision is by definition political. In uncertain situations, second-guessing the consensual decision of the governments of all members (assuming they are themselves democratic) could be a thorny task for an international court.

The most virulent criticisms addressed at the Mendoza decision, in fact, do not concern the merits of this particular decision but rather the inconsistency in the formulation and application of the so-called 'democratic clause' provided by the Ushuaia Protocol. The clause, it is argued, is under-inclusive, as it fails to address situations of 'democracy erosion' by charismatic leaders and domination of other branches of government by the executive-phenomena common in some of the South American 'Bolivarian' Republics. Additionally, the application of the clause against Paraguay would have more to do with the political inclinations of the toppled (left-wing) and instated (centre-right) governments than with the preservation of democracy itself.

Similar claims of inconsistency are often addressed to political organs on all levels (starting with the UN Security Council and General Assembly). The terms of the Ushuaia Protocol are broad enough to encompass both traditional coups and erosion of democracy. It would perhaps be more productive, if one's intention is to protect democracy, to take the case of Paraguay's suspension as a precedent, and to call for similar application of Ushuaia Protocol sanctions to like cases in the future, than to demand that the clause not be applied at all. In a region that has all too often succumbed to non-democratic 'waves', a mechanism whereby democratic governments may support each other-and sanction breakdowns of democracy in their peers-should in principle be preserved and allowed to function. 